\title{
Del desencanto al encantamiento del mundo: el cuerpo de los sueños y el cuerpo presente
} From Disenchantment to Enchantment of the World: Dream body and the present body María Cristina Fuentes Zurita Universidad Autónoma Metropolitana, Unidad Iztapalapa, México ORCID: http://orcid.org/o0oo-000I-7230-6I03 DOI: http://dx.doi.org/IO.28928/revistaiztapalapa/822017/atcI/fuenteszuritamc

\section{Resumen}

En este artículo se presenta el trabajo de intervención social de I 3 piezas de performances de mujeres trabajadoras y/o habitantes del centro histórico, dirigidos por Lorena Wolffer y la colectiva "Territorios de Cultura para la equidad", realizados durante el 20IO. El objetivo es mostrar el modo de producción de actos performativos donde el cuerpo se manifiesta, creando cambios de vida en espacios para la fuga e intersubjetividad, en el centro de la ciudad. Pequeños actos colectivos, que son parte de una nueva política de la presencia, donde este arte crea resistencias desde las emociones y el respeto. Palabras clave: Cuerpos, emociones, performances, modo de producción, intersubjetividad.

\begin{abstract}
This article describes the social intervention work of 13 performance pieces by women workers and/or residents of the Historic Center, led by Lorena Wolffer and Territories of Culture for Equity, made in 2010. The objective is to show how the production of performative acts - where the body manifests itself-creates life changes in spaces for escape and intersubjectivity in the center city. This art illustrates that small collective acts, which are part of new politics of presence, creates resistance from emotions and generates respect.
\end{abstract}

Keywordsः Bodies, emotions, performance, production mode, intersubjectivity.

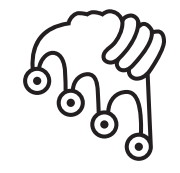

\section{IZTAPALAPA}

Agua sobre lajas

mcfuentesz.fuentes2@ gmail.com 


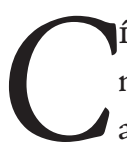

ÍrCULO, CIRCULAR, COMO UNA ESFERA QUE GIRA EN ARMÓNICOS MOVImientos de rotación y traslación, esta es nuestra tierra, nuestro planeta, o al menos debería serlo. Globo, global, como esfera que aspira a ser justa, democrática, igualitaria; sin embargo, el mundo se ha metamorfoseado en un cubo piramidal, con una larga base de trabajadores, de humanos inertes, dispuestos en cuadrículas alineadas como rígida losa de piedra.

A esta estructura nuestros científicos políticos, económicos y sociales han dado el término de globalización. Nombre sin sentido, antítesis de formas y estructuras que jamás pueden anhelar compartir devenires, destinos, afectos, comunión. En un sinsentido de tiempos, espacios y existencia. Hoy la mayoría de la población no tiene tiempo para sentir los pequeños encantos y rituales cotidianos de vida y gozo, sin oportunidad para interacciones e intercambios de amabilidades, de amor, de cantos para elevar el ánimo, de entregas, de respeto. Sin espacios para la amistad, ni con uno mismo, qué decir con el otro. Sin existencia para la paz, para cuidar de la tierra, del aire, de los ríos, de los seres-hermanos-menores, de todos.

El mundo ya no es redondo: es piramidal y además se está acabando, y las ciencias sociales desgraciadamente han ayudado a que esto ocurra. Preocupados por controlar, hemos construido muros llenos de normas y reglas por seguir, desvinculando a los seres humanos de sus cuerpos, de sus emociones, de su creatividad, del arte de vivir, produciendo cuerpos domesticados, homogeneizados, con la ayuda de la tecnología. Los hemos arrancado del contacto consigo mismos, de la naturaleza, del cuidado de sí y de su entorno; sin momentos para el ocio, para pensarse desde el afecto.

Enajenados en ciudades globales, desiguales, "sin consciencia común de la existencia" (Therborn, 2013: 14), sembradas de consumos en cada esquina, o durante el recorrido agotador de largos trayectos, en largas jornadas de trabajo, viviendo desde el enojo y el resentimiento, peleando por un espacio donde alojarse. Sin tiempo para construir un lugar interior y exterior donde pensarse, nos alojamos en jaulas de cognición que se traducen en cuadros, en trayectos ya trazados, en cartografías heredadas, depositando el cuerpo en sueños de plazas comerciales o 
clubes deportivos como si fueran el lugar para encontrarse, clamando protección a cualquier líder, con la ilusión de que nos cuide y guíe. Estamos en la supervivencia.

Necesitamos urgentemente reconectarnos y reinventarnos: con pensamientos críticos hacer cambios con todo y el cuerpo, fluir, atravesar umbrales junto con los otros, no solos. Construir utopías en este momento distópico. Necesitamos ya no repetir-nos, ni un gesto, pues el cadalso ya está aquí. La ciencia cartesiana nos sacó de la escena, separando nuestras emociones del cuerpo, de la mente, rompiendo los flujos, el lenguaje, la comunicación. Negando dirigir la mirada a la subjetividad, los deseos, la manifestación del ser. Hicimos investigaciones sin sujeto, sin deseos de vida, inertes, perdidos en un sinsentido de acumulaciones y atesoramientos materiales, de edificaciones de siempre pequeños egos. Necesitamos revalorar nuestros conocimientos, producirlos con nuevas miradas metodológicas, donde un cuerpo más libre y presente se manifieste en un baile armónico y respetuoso con los otros, con el cosmos, con la vida. Si no, feneceremos...

Si nos ayudamos a pensar con la obra de Max Weber sobre los efectos del capitalismo, él ya anunciaba de alguna manera este desastre, y para comprender no solo las formas sociales, sino también las culturales, nos habló del desencanto del mundo por la cárcel de la razón. Es decir, si el hombre únicamente se sumergía en ella, no estaría bien. De hecho, explicó este desencanto por sus observaciones de la separación de la esfera religiosa, de la vida cotidiana. Tal parece que eso hemos venido haciendo, pues nos ha importado más la alienación poco consciente en el trabajo, del estar bien, al dejar de lado las experiencias subjetivas, lo que percibimos, el valor de las interacciones llenas de sentido, gestos o acontecimientos empáticos. Nos hemos alienado con nuestro ethos cultural y nacional sin actualizarlo, sin cribarlo por el tamiz de los derechos humanos. Weber (1968:20) explica cómo ante este desencanto opera la fuerza del carisma de los líderes; importando la misión, no sus programas.

Fue Maffesoli, desde los años ochenta y hasta su obra reciente, quien habló de un reencantamiento del mundo al observar en la sociedad la presencia de las emociones y las estéticas, como una crítica creciente a la razón, a las instituciones, sus normas y finalmente al Estado (2010: 37; 2014:39). A cambio surgió una emergencia del cuerpo, del juego y del estar juntos, es decir, de la necesidad de afecto, de ser vistos, de ser. Así lo presentaba en sus libros, no sin antes aceptar que eran tiempos trágicos, no de construcción moderna sino de regreso de las tribus. Habla de la presencia del pensamiento de Nietszche, quien invitaba a iniciar nuevos viajes, a zarpar a nuevos mares, nuevos conocimientos, con el cuerpo de vuelta. Recordemos que ya antes Lyotard había realizado la crítica a los grandes metarrelatos; Deleuze 
y Guattari observaban otra forma de producción de la realidad, multidimensional, más orgánica, rizomática, con trayectos no lineales sino a través de intersticios, de bordes, donde habitaban los deseos y los afectos.

Foucault, Derrida y el pensamiento feminista de Judith Butler de la mano del primero, retomaron los estudios de los disciplinamientos del cuerpo, de los dispositivos que los producen, de los modos de producción. Pensamientos sin duda críticos. Así llegamos a la estética, a los estudios de género y a las intervenciones sociales como los performances de los que hablaremos. Pasamos de estudiar la realidad a cómo re-construirla. De querer hacer ciencia a estudiar la cultura, a querer hacerla y vivirla. A estar encantados actuando, no representando. Desde la academia, algunos ya no nos conformamos con acompañar los problemas de un grupo social o de una comunidad, sino realmente se trata de hacer comunidad con la gente, en este caso que nos ocupa, con mujeres, y que sean ellas las que desde su acting colectivo sostengan su mundo o lo cambien, y nos inviten a hacerlo. Ya no más pensamiento colonial, racista, sexista, machista, clasista. A partir del libro Ante el dolor de los demás, de Susan Sontag (2004), no solo miremos, metamos el cuerpo.

\section{Contexto sociopolitico de las demandas al cuerpo presente}

Desgraciadamente tuvo que haber muchas muertes para que en 2007 el gobierno mexicano aprobara la Ley general para el acceso de las mujeres a una vida libre de violencia. Dos años después, en 2009, se formalizó la comisión para prevenir y erradicar la violencia contra las mujeres, lo que representó la ejecución federal. Se lanzaron en el país recomendaciones para desarrollar y apoyar medidas necesarias en todas las instancias gubernamentales y para involucrarlas en la atención al tema, al otorgar financiamiento a través de concursos a proyectos de investigación diversos, así como de intervención. Se apoyó a aquellos que ya estaban en marcha, al igual que a algunos nuevos. Llegar a esto fue una labor intensa por parte de grupos feministas y aliados. Implicó iniciar un cambio de mentalidades (que aún no termina, ni terminará) sobre el género, los géneros, por parte de los mismos hacedores de políticas públicas. El tema del acceso a los derechos está abierto al cambio y fácilmente retrocede.

Realizar la gran sensibilización que el tema requiere siempre ha estado a cargo de activistas y la sociedad civil, financiadas por organizaciones internacionales, un trabajo de academias nacionales e internacionales. La ceguera partidaria, religiosa, sumada a los intereses hegemónicos sobre las identidades y el consumo de lo femenino o masculino minimiza el problema de la muerte de las mujeres, 
culpabilizándolas al utilizarlas solo como electoras, sin reconocer que el fenómeno del feminicidio se había generado, en términos generales, por la globalización de los años ochenta y la falta de cultura y educación para enfrentar el tema de violencia sexual y de género. El desajuste que la nueva economía asestó a los sistemas de género naturalizados, y a las identidades en general, las fracturó, multiplicó las distancias existenciales y sacó a la luz, con mucho dolor, problemas sobre libertades y derechos. Los comportamientos sociales de las mujeres y los hombres estaban regidos por normas y costumbres que trazaban roles ya enfermos, de subordinación y autoridad; ${ }^{1}$ ante el miedo, avanzaron la misoginia y machismo. La agencia de las mujeres estaba en ascenso y los hombres se sentían cuestionados, no reconocidos, perfilando victimarios "para demostrar y perpetuar la dominación" y una hecatombe en todas las relaciones humanas -amatorias-(Domínguez, 2015: 26). Esto ocurría no solo en México, debido a la "naturalización de la violencia" (Expósito, 2013). ${ }^{2}$ Los proyectos de educación y formación, en los cuales fraguar las alianzas como espacios de reflexión sobre lo que ocurría y se expresaba en las emociones y en los cuerpos, y que incluían los comportamientos y la sexualidad eran muy importantes, sin una mirada clínica y medicalizada. La crisis de identidades, de alteridad, de justicia y de libertades existenciales nos mostró el lado obscuro de la impunidad, del atraso de la violencia sexual y de género.

En este contexto se realizó el proyecto de Cuerpos manifiestos que nos interesa abordar en este artículo. Durante 2010, Territorios de Cultura para la Equidad, ${ }^{3}$ conformada por cuatro valerosas mujeres, quienes ya venían trabajando con trabajadoras y/o habitantes del centro histórico, en alianza con la oficina de Servicios Urbanos,

1 Sobre las desigualdades de la salud de las mujeres debidas a razones sociales y culturales véase el informe Determinantes sociales de la salud de la Organización Mundial de la Salud, oms, 2008-2013.

2 En noviembre del 20I4, en la Universidad Autónoma Metropolitana, Unidad Iztapalapa, se celebró el Seminario Internacional de Investigación "Perspectivas de estudio sobre las masculinidades" que organicé junto con Jacob Flores. En este marco, la doctora Expósito presentó la conferencia titulada "Naturalización/desnaturalización de la violencia", donde afirmó que hablar de violencia de género no es hacerlo de los hombres como sujetos violentos, es discutir una problemática social.

3 Antes Agrupación, ahora Colectiva feminista, conformada por Pilar Muriedas, Aurora Montaño, Maricarmen Velasco y Janina Ávila. El proyecto marco era "Corazón Seguro, ciudadanía cultural desde las mujeres para la seguridad en espacios públicos". 
de la ahora Ciudad de México, confluyeron con la propuesta del Centro Cultural de España para realizar un taller de performance con la artista Lorena Wolffer. ${ }^{4}$

El proyecto tuvo la finalidad de tomar el espacio público de la ciudad con la presencia de mujeres invisibilizadas ante las políticas culturales. El corazón del centro histórico sería el escenario, incluido el zócalo y sus calles aledañas, el exconvento de Santa Teresa y el mismo Centro Cultural de España, igualmente ubicado en el centro, en una casona del tiempo de la colonia. ${ }^{5}$

La tesis del proyecto era que, al realizar un taller de performances, el grupo de 30 mujeres participantes, en tanto ciudadanas, adquiriría legitimidad y poder desde su acción y su discurso, al re-nombrarse. Al tomar la iniciativa de realizar una serie de actos performativos y performáticos durante tres meses y vivir las experiencias que las movilizarían a mostrar sus cuerpos encarnados, con aquello que las hacía sentir fuertes y al mismo tiempo vulnerables. Fuertes por - en sus piezas - tomar la voz, vestir un traje de policía o del servicio de la limpieza dignamente, en un escenario, por ejemplo, y ser vulnerable por ser mujer en este contexto, les permitiría hacer un movimiento, vivir una transformación, un giro de tuerca al hablar de sus vidas, al mofarse o denunciar o ver de lejos y criticar a quien critica su trabajo, su vida misma, y a quien pone en duda la valía de una mujer.

\section{Producción de los performances de Cuerpos manifiestos, con Lorena Wolffer}

\section{Definición de categorías}

Existen diferencias entre los términos: performance, performativo, performatividad, y se basan en la teoría desarrollada por John L Austin, explicada en su texto de 1955,

4 Lorena Wolffer (Ciudad de México, 197I) es una reconocida artista y activista cultural feminista. De 1992 a la fecha ha realizado cerca de 80 proyectos, además de curar, producir y facilitar numerosas exposiciones, cursos, talleres y programas tanto de televisión como de radio. En 2014 recibió el premio Artraker Award for Social Impact en Londres, Inglaterra, por la intervención cultural Espacios de excepción. En 2015 presentó la muestra documental "Expuestas: registros públicos" en el Museo de Arte Moderno de la Ciudad de México, que constó de trabajos desarrollados entre 2008 y 2015 y que comprendieron más de 20 proyectos que giraban en torno a la violencia contra las mujeres en la actualidad en México.

5 El siguiente proyecto de Territorios se llamó Corazón seguro, y se realizó en 20 ir en la Alameda, el Museo Franz Meyer y el de la Alameda. En este se incluyó a más mujeres: taxistas y meseras de Sanborns, jubiladas, discapacitadas crónicas, estudiantes-desempleadas, vendedoras, etcétera. 
Cómo hacer cosas con palabras. El término performativo es un concepto derivado del verbo to perform 'realizar', siendo la performatividad la reiteración de actos del habla (Fischer-Lichte, 20II: 48). Performance es utilizado, según Taylor (20II: 7), como ejecución o actuación. Como ejecución se asocia semánticamente con un hacer o con actualización o puesta en acto; como actuación evoca significados de presentación delante de una audiencia, o como puesta en escena. Butler (2002: 18-I9) habla de actos del cuerpo: la repetición performativa termina materializando cuerpos e identidades.

Como señala Diana Taylor, "los performances operan como actos vitales de transferencia, transmitiendo el saber social, la memoria y el sentido de identidad a partir de acciones reiteradas" (2012: 22). Los términos de performance, acto performativo, performático no son sinónimos, aunque siempre aparecen juntos, y es difícil diferenciarlos en la escena. Corresponden a diversos trabajos teóricos y vale la pena entender cada uno, pues aquí se habla de performance en general. También nos dice Erika Fischer-Lichte (20II:8) que el performance es presencia, cuerpo, percepciones, sensaciones, sentidos y Bishop (2016:49) lo ubica en la aísthesis, en la práctica del sentir, más que en el campo del tratado estético. La estética de lo performativo que aparece con fuerza en los años sesenta y setenta del siglo pasado es más del orden del acontecimiento, de lo que se realiza, de la energía o de la realidad que se crea y aparece con el arte. De lo que se transforma, de la acción, más que de lo que significa - algo estudiado por la semiótica o la heurística explicativa-, ya que no dejamos de intentar explicarlo o comprenderlo.

Es crear otras realidades, lo cual resulta muy interesante en las nuestras, regidas por el corporativismo, la violencia y un ethos comunitario tradicional, conservador, ya obsoleto. Estos ejercicios, basados en los derechos, trabajan por la libertad, la voluntad del individuo de ser, de indignarse, de ser un humano con valía, con todos los límites y determinantes de su persona y su contexto. Además, hablar de performance o performances permite ampliar la mirada interdisciplinaria hacia un análisis transdisciplinario que ubica el acto performático como una acción determinada desde el cuerpo y pasa por la performatividad que construye el individuo que lo ostenta, entendiéndolo como un cuerpo con dimensión física y subjetiva (Varela, 2016: 57-60; 75-79). De tal manera que el sujeto, en tanto actor, se permite ser autor.

Para Bishop (2016: 37), el performance que inició en los años ochenta sería, cada vez más, un acto político. Este valoraba en su momento la inmediatez y la presencia del cuerpo del artista; sin embargo, en la década actual, la autora considera que el valor ya no se asocia al artista sino al cuerpo colectivo con quienes se lleva a cabo el acto. 


\section{Objetivos particulares y método del proyecto}

La idea fue producir y afirmar una comunidad de mujeres con una postura política feminista, basada en el acceso a derechos culturales, a la información, al ocio, y al goce. Para ello se trabajó en el performance con lo emocional como acto político. Se trató de tomar el espacio público como un espacio político y diseñar la ciudad con cuerpo de mujer. Se puede decir que el método o procedimiento utilizado en la realización / producción de los performances fue generar un proceso de cambio somático, psicológico y emocional individual en un grupo de mujeres y sus públicos.

\section{Los talleres, los escenarios, las presentaciones}

Nos reunimos todos los miércoles durante tres meses y se inició un proceso; en cada sesión fuimos preparándonos en sensibilidad y emociones para desarrollar y presentar piezas individuales sobre nuestros cuerpos manifiestos en el corazón de la ciudad. Antes de la realización final en el Centro Cultural España tuvimos un ensayo general ante todas para pulir, con Lorena Wolffer, cada pieza, desarrolladas individualmente y poco a poco; de ese modo, durante las reuniones del taller se fue produciendo, en nosotras mismas, el material para realizar las piezas finales

\section{Los espacios de presentación, tiempos}

El grupo se fortaleció al efectuar acciones conjuntas que dieron lugar a vivencias específicas con espectadores diversos. Se hicieron varias presentaciones con formatos diferentes, dependiendo de los espacios: en el centro cultural de España, en el kiosco de derechos humanos de la feria del libro del Zócalo, y en La Casa de la Primera Imprenta de América de la UAM. Muchas de las experiencias fueron liminares, umbrales como las trabaja Van Gennep y posteriormente Victor Turner, "algo así como un estado de excepción en el que la compartimentación de atributos, roles o identidades se desvanece" (Stavrides, 2016: I0), en el sentido que implicaron un proceso de transformación de las participantes, de miembros de un grupo a un colectivo, con transformaciones sociales en espacios de entre dos. Los espacios fueron dispuestos, en esas presentaciones, como dispositivos transicionales de los que nos habló Donald Winnicotte en su obra. 


\section{Desarrollo y presentación del trabajo de Cuerpos manifiestos}

Algunas de las mujeres participantes invitadas ya habían trabajado en proyectos anteriores de Territorios de cultura para la equidad. ${ }^{6}$ Llegaron gracias a las diversas negociaciones que se realizaron con sus jefas y jefes para asistir todos los miércoles, durante o después del horario de trabajo, de cuatro a ocho de la tarde, y lo hicieron solas o en grupos de compañeras conocidas, después de amigas y al final ya de comadres.

Primero se explicó de manera general en qué consistía el proyecto de Cuerpos manifiestos, que nos llevaría a crear piezas de performances con ciertas metodologías participativas y trabajos vivenciales, las cuales se prepararían durante tres meses, para finalmente escenificarlas en el Centro Cultural de España. Nos presentaron a la que sería nuestra maestra, quien nos explicó su arte a grandes rasgos, lo que haríamos con lenguajes estéticos en las siguientes sesiones: no actuar, tampoco representar, sino durante tres minutos presentar nuestras vidas con el cuerpo y algunos objetos.

En esa primera presentación formal éramos cerca de 35 mujeres, número que siempre variaba, lo que ocasionaba que en ciertas sesiones algunas serían espectadoras y/o actoras, dependiendo de la asistencia. Todas las mujeres, como en una ceremonia especial, en círculo, tipo ritual, dijimos brevemente lo que hacíamos y quiénes éramos desde otro lugar, nuestro trabajo y vida cotidiana. Así se estableció el lazo.

Fue en cada sesión, en ese espacio creativo, donde se vincularon las diferencias y los tiempos. El espacio de las afrentas, de las culpas, de las incomodidades, y se proyectó, desde el cuerpo, pensándolo y sintiéndolo, un ser de sueños y demandas. Se construyó un espacio social de múltiples dimensiones, entre el pasado, el presente y el futuro. Y se propició un espacio de intersubjetividad, de transmisión e intercambio de ideas, dejándose afectar unas por otras; hablando y escuchando atentamente y sin juzgar. Así se logró expresar desde el cuerpo lo que eran realidades en el trabajo del centro histórico o fuera de él: en sus casas, en el transporte público, y se filtró la vida y lo que se había vivido.

Tres meses después, durante la presentación de las piezas ante los espectadores, se creó un espacio de inmersión, de transformación, porque las mujeres se hicieron presentes, se manifestaban cuerpos con mente, embodied-mind. En cada ensayo,

6 Algunos nombres de trabajos anteriores son: "No me gustan las manzanas", "El sexo oculto del dinero," “De la vía pública a la Vía Láctea”, entre otros. 
entre actores y espectadoras, surgió la magia del cambio de roles. $\mathrm{Al}$ ponerse en el lugar del otro ya no se sabía quién era el sujeto percibido o quién el espectador, el de la percepción; lo mismo ocurrió en las presentaciones con otros públicos. Para explicar esto Fischter-Lichte (2011:325) nos habla de la realización del giro autopoiético de Varela y Maturana, que consiste en la autoproducción.

Así, en estos ensayos semanales se construyó entre las mujeres otra intersubjetividad, donde la empatía y el respeto aseguraban el verse como iguales, fuera de las lógicas jerárquicas del poder/saber, de clase, etc. Éramos muy diversas: policías, trabajadoras de limpieza, vecinas amas de casa, estudiantes, profesionistas. Al borrar las diferencias por un momento, hablándolas y actuando las injusticias se compartieron emociones, sentimientos. El proceso artístico tocó la imaginación moral y trabajamos el alma y el acto creativo procuró algunas semillas de sanación (Lederach, 2016: 304). Fluctuábamos entre representaciones escénicas artísticas y no artísticas. Algunas se proponían objetivos, otras no. Primero reíamos, luego llorábamos o, por el contrario, otras solo hablaban, enojadas o inquietas. Esto se logró a través del trabajo en los talleres, del trabajo escénico de cambio de roles y de percepción, al realizar ejercicios para activar los sentidos y mover las interpretaciones. Además, hicieron que nos fijáramos y realizáramos en actos performáticos de lenguaje de Austin, no solo en practicar o fijarnos en los usos lingüísticos (de Wittgenstein) que llevan a gestos que nos repiten, a silencios que nos separan. Nos lanzábamos al vacío, navegábamos la incertidumbre y nos producíamos ahí mismo para comunicarnos, no afirmarnos, para crear intersubjetividad.

Nos podríamos preguntar si esta relación entre cuerpo y sentido común emancipa. Pero estamos de acuerdo con Fátima Flores Palacios (2010: 336) en que investigar el sentido común de las mujeres refiere a lo que sienten y piensan. Esta autora lo hace desde la confluencia de la teoría de las representaciones y la teoría feminista, pues, como dice, no se trata solo de comprender su situación sino también de actuar. Para esta autora en ambas propuestas teóricas se manifiesta la importancia de las dimensiones subjetiva, afectiva y cultural en la construcción del saber y en las acciones humanas. Para tocar estos asuntos la teoría feminista ha estado también interesada en desarrollar metodologías que aborden las emociones de las mujeres y el poder, y es el caso de la postura asumida en el tratamiento del equipo de producción de estos performances, para lograr que las mujeres tomen consciencia de su situación, con todo y el cuerpo, y se sientan un poco liberadas, es decir, se emancipen, se des-sujeten de los poderes que las alienan y dominan, aunque sea por unas tardes. 


\section{Ejercicios en los talleres}

En el primer taller actuamos otros roles, nos citamos en el Zócalo disfrazadas como el personaje mujer que generalmente no somos y de entre las policías, estudiantes, barrenderas surgieron las amas de casa con tubos, las prostitutas, las mujeres perdidas. Tenían que interactuar con los transeúntes con algún motivo, muchas pedían un peso para completar el boleto del metro o solicitaban les sacaran fotos.

En el segundo se trató de mirar con los ojos cerrados las calles del centro, presentadas por otra compañera, caminando a su lado y confiando en el tacto sugerido por una de ellas (a la que le correspondía guiar durante el trayecto) y después en alternancia con su par. Siempre se creaban momentos de sorpresa y de zozobra, desmarcándose y abriéndose a otros referentes posibles; por ello se habla de intersubjetividad.

En las siguientes sesiones se activó la percepción, la confianza y la imaginación para construir más que representar una pieza, produciéndola, y en cada sesión hacíamos un ensayo sobre nuestras vidas. Transversalmente, se tejía una gran red de concordia, de fraternidad, de apoyo y se realizaban pequeños actos sanadores, pequeños rituales, al ofrecer al colectivo una vela, una flor.

Las pequeñas piezas individuales de arte creativo y sanador nos llevaron a descubrir vivencias cotidianas, sueños y necesidades inscritas en el cuerpo; se alimentó a la artista que se lleva dentro, y salió lo que ya estaba en el interior de cada una, y que por un momento dejaba de lado la representación del diario trajín, la resistencia de cuerpos para la lucha o el del desagravio sufrido por muchas. Fue ahí donde las mujeres realmente se fueron presentando o más bien haciendo sujetos, ayudadas de la ficción, de las historias de las otras, y decían lo que eran, lo querían ser o hacer, para salirse de situaciones incómodas. Cada miércoles se armó un colectivo de mujeres en reparación, que empezaron a bordar sueños... con todo y sus cuerpos.

\section{Cuando hablamos del video de los performances}

El registro visual del trabajo del proceso y de la presentación de los performances, así como este escrito, tuvo como interés dar cuenta de la producción de otros modos de estar en la vida de un grupo de mujeres, después de tomar la voz con todo y el cuerpo, junto a una comunidad que también vibraba. Era la propuesta feminista de las organizadoras, gracias a la representación escénica del performance. Con el video de algunas piezas se quiso dar cuenta de la existencia de trabajos feministas 
de un grupo de mujeres, donde de alguna manera se produjo un proceso de sanación en cuerpos enfermos, molestos, dolientes, al mostrarlas, a ellas mismas, en sus esfuerzos por estar bien.

Fue un video a cargo de la antropología visual, el cual tiene como interés el trabajo colaborativo con las comunidades, como postura ética (Zirión, 2015ः46), sin olvidar que la última obturación o recorte los hace el editor. José Manuel Escalante ${ }^{7}$, quien filmo y editó, tuvo que preguntase qué dejaba ver. Para él también significó una profunda reflexión y un cambio en su vida, según dijo. También se partió de proponer que las emociones producidas por el video generan otro tipo de conocimiento que las incorpora. Cuando volvimos a ver las escenas en el video (más allá de la parte técnica, de cuadros, planos, luces, etc.), así como las entrevistas a las mujeres actoras, en la realización de cada uno de sus performances, nos conmovimos, nos indignamos, nos molestamos, involucrándonos de nuevo con esas mujeres, pues como anota Maalouf (20I2) en la contraportada de su último libro: Los desorientados, : "perdemos la memoria de las palabras, pero no la memoria de las emociones".

Los títulos de los performances fueron diseñados con Lorena, muchos de ellos como metáforas de las producciones individuales realizadas: "Mis años maravillosos", "Arte sano", "Sonríe," “Familias", "Mata a un estudiante y harás patria”, "Presencias", “Nunca esperes más”, “Ah”, “YYa no más!”,"Lo que piensas de mí”."Mi cuerpo es mío", “Hace seis meses”, “Tan iguales y tan diferentes”,"La injusticia de la justicia”, “Re-formada”, “Cómodas?”, “La pieza son ustedes," “Amenaza cumplida”, "Aprendiendo a caminar", "El confesionario", "Luz-power", "Perlas de cultura”, "Reconocimiento sin cohecho".

\section{Algunas de las piezas videograbadas y las cartografías existenciales}

Las cartografías existenciales tienen que ver con el devenir del sujeto y sus rupturas, con los cambios de los modos de ser y estar, son de corte deluziano y recientemente han sido desarrolladas como metodologías para investigar trayectos de construcción de "subjetividades otras" por Claudia Piedrahita. ${ }^{8}$ Aquí se utilizan, brevemente, para dar cuenta de los trayectos que siguieron algunas de las mujeres participantes

7 Técnico del Laboratorio de Antropología Visual de la UAm-Iztapalapa.

8 Trabajo presentado como ponencia magistral en el Congreso de Clacso en Medellín 2015, con ella dio cuenta de su investigación de formación crítica en maestros colombianos de educación secundaria. 
que se pudieron contactar, o saber de ellas, después de la experiencia realizada en el taller y de las presentaciones de los performances. Otear un poco su acting, su potenciación, sus cambios, sus vueltas de tuerca.

Del equipo de producción y de entre las invitadas, solo algunas pudimos participar desde un principio. A Aurora Montaño, gestora cultural, le era importante, por una cuestión ética, implicarse en los procesos de las compañeras, exponerse, y a mí comprender lo que era una intervención, viviéndola. Ambas nos dejamos afectar y no resultó una intervención, sino la participación en la producción de una comunidad intersubjetiva de apoyo; vivimos un nuevo conocimiento desde el cuerpo, desde los afectos, y cambiamos de cuerpo; al dejarnos tocar (afectar), y hacer vínculos nunca volvimos a ser las mismas.

I. Re-formada, fue la pieza que presenté sentándome en una silla en el estrado, después de haber molestado a todo el público durante la presentación de otras piezas; los tocaba por el hombro y pedía permiso para pasar y recoger unas piedritas de río, antes del inicio esparcidas por el suelo del espacio donde se ubicaría la audiencia; algunos estaban tan atentos que por la interrupción volteaban y me veían molestos. Ya en mi turno, subí caminando tranquilamente, me senté en una silla, único objeto en el estrado, teniendo una proyección enorme a mis espaldas de una pintura de una mujer hermosa y pasada de peso, recostada sobre un diván como una Goya, tranquila y abrazándose un seno.

Empecé por comentar lo difícil que había pasado los últimos años "en el ajetreo del trabajo, la ciudad, la casa, estresada, siempre corriendo", al mismo tiempo que me sacaba de un seno las piedritas antes recogidas y las ponía en una cajita adornada con estrellas, lunas y letras antiguas, invitando al público a soltar la prisa para hacer contacto consigo mismos, en el diario devenir, a no olvidar tener momentos para conversar entre amigos y amigas, gozar, reír y tener más trabajo personal, de respiración, de relajación y con las emociones, descubriendo haber tenido cáncer hacia un año. Me comprometí frente a ellos a tener, cada vez más, momentos de arte sanador en ese espacio del Centro histórico; de tantas confluencias energéticas, tan poderosas. Tener más momentos de encuentro y de paz conmigo y con las compañeras. Terminó mi acto, invitándolos a escuchar música y prendiendo un listón rosa en el lugar de mi seno derecho, recién operado. Para terminar, desplegué mi abanico y le pedí a "Sombra”, el técnico que nos apoyaba en la producción, "música maestro." Durante un minuto todos escuchamos el inicio de la canción de Las ciudades, cantada por Chabela Vargas, 
Te vi llegar...

y estuve a punto de cambiar tu mundo por el mundo mío.

Cartografía existencial. Al centro de la ciudad regreso a la menor oportunidad, saludo a mis compañeras, convivo con ellas. $\mathrm{Al}$ año participé en otro trabajo de performance con Lorena y Aurora creando "Puentes", marchando sobre el Zócalo de la ciudad junto con 20 mujeres. Durante varios miércoles más, nos apropiamos del espacio público, ahí estábamos y nos tenían que respetar. Yo realicé mi compromiso gozosa, al soltar la prisa, detenerme por momentos, y ahora después de estos años llegué a las letras. A poner en blanco y negro esta experiencia tan transformadora.

2. ¿Cómodas? En este performance irónico, sí te ríes: vemos a una gestora cultural, Aurora, actuando como lo que se supone que es, pero totalmente incómoda por sus artefactos, atrapada en unos bastidores de mesa de centro de sala, queriendo salir para tomar la forma de diversas imágenes de cómodas proyectadas en la pared, muebles antiguos del siglo xvI, hasta un secreter pequeñito; cómodas altas, bajas, estilizadas o anchas. Ella con vestido negro, bolsa de mano, entre collares y rizos y zapatos de tacón con correa al tobillo, que se atoraba en los bastidores. Esa imagen fue él clímax dramático de su performance: vimos durante casi un minuto cómo terminó desabrochando la pequeña hebilla para quitarse el zapato y poder liberarse.

En entrevista con Aurora nos dijo que lo que quería transmitir era exactamente eso, la incomodidad del cuerpo al representar el papel de una mujer acomodada. También, dijo, "en ese sector de mujeres existe el agobio de cubrir las formas".

Cartografía existencial. Terminó cortándose el cabello casi a rape para dejarse sus canas y no volver a pintarlo jamás. Estuvo durante dos años asistiendo al Hospital de Nutrición para regular su salud y su peso y transformó su guardarropa con bellos huipiles. Se adhirió a varios colectivos de huertos orgánicos y en su casa puso un hostal en donde de preferencia recibe a defensores(as) internacionales de derechos humanos y de mujeres. Asumió su edad y los 60 años los festejó brindando en su primer viaje por el metrobús, con su credencial del INAPAm. Le costó trabajo dejar su vida anterior, la cual ya no era "Cómoda", ni lo estaba; siguió haciendo proyectos para mejorar "el estado de tu corazón en el centro histórico con mujeres". Acompañó el paso a otra vida de un querido amigo, y su presencia, que siempre fue y es amorosa, se abrió a nuevas relaciones amatorias-virtuales $y$ presenciales y a una vida sin deudas, desprendiéndose de su arte colonial. Ahora construye su vida con arte. 
3. Presencias. Verónica, trabajadora de limpieza del centro histórico sube al escenario enfundada en su uniforme, muy bien maquillada; nos habla de las calles del Centro histórico y sus leyendas, para platicarnos cómo por las noches, durante su trabajo de barrido, hay seres que están ahí y ella ha pensado que la acompañan. Fija su mirada en los espectadores y señala con el brazo extendido y con la mano a una "presencia" entre el público y pide les hagan lugar, diciendo al mismo tiempo que mueve y señala con la mano que le hagan espacio, "ahí, hágase a un lado por favor", y mirando y señalando en otro punto entre los asistentes dice, "ahí también, por favor, a un lado, ¿qué no los ven?", termina inquiriendo.

Cartografía existencial. Sigue en el barrido, "siempre ha sido jefa", me dicen. Ahora trabaja en los depósitos, distribuyendo el material necesario para el barrido y el pintado de las calles del Centro histórico.

4. Tan iguales y tan diferentes. Verónica, policía del Centro histórico, era del grupo las Gacelas. Es delgada, alta, joven. Sube a escena perfectamente uniformada, maquillada y con quepí. En la escena hay dos sillas; se presenta con el saludo obligatorio de la policía nacional y después se sienta, se quita las botas y el gorro, dejando caer su larga y cuidada cabellera, pintada con rayos dorados y rojos, la mueve de un lado a otro y empieza a desabrocharse el saco para quitárselo, al tiempo que dice: "al llegar a mi casa saludo a mi hijo, a mis padres y me relajo, me cambio, y como todas las mujeres que trabajan, me pongo cómoda, prendo la tele, la música o hablo por teléfono". Todo esto lo hace soltando el cuerpo, relajándose y colocando en la otra silla, el bombín, el saco, el cinturón con la pistola. Finalmente queda en un top de licra y dice al público: "porque como todas las mujeres, somos iguales, sensuales, únicas e irrepetibles", mostrando al mismo tiempo letreros con estas palabras, cartones que se encontraban en el asiento de la silla que sirvió de perchero.

Cartografía existencial. Actualmente este grupo fue desintegrado y ubicado en puestos diferentes de la ciudad. Habían sido asignadas al cuidado del Zócalo, del corazón de la ciudad y elegidas por ser las más bellas. Se casó.

5. Reconocimiento sin cobecho. Verónica, policía del centro histórico llega a la escena con su hija de io años. Ambas perfectamente arregladas y enfundadas en sus uniformes, la madre con el de policía y la hija con el de estudiante de primaria. Junto a un asta con la bandera mexicana, le entrega a su hija el premio por haber sido la mejor estudiante de su grado y de manera simbólica efectúa un movimiento de brazos que simula el acto de entregarle la bandera diciéndole que sabía que era ella y no la otra chica la que debía portarla, en la escolta y "con orgullo". Pero debido a que ella, policía, no había aceptado el soborno que le habían pedido, la institución 
educativa optó por no dársela. Ella ahora, su madre, en el performance le hacía esa ceremonia para resarcir su esfuerzo, al tiempo que denunciaba ese hecho.

Cartografía existencial. El día del evento no pudo llegar, pues en el último momento la cambiaron de turno y la enviaron muy lejos. En el video aparece su pieza grabada del ensayo anterior, en el preestreno. Su hija sigue muy bien en los estudios.

6. Mata a un estudiante y harás patria. Verónica era estudiante de la Facultad de Psicología de la UnAm y estaba consternada por la muerte de su mejor amigo a manos de la policía en Monterrey sin motivo alguno. Fue un caso reportado. Con una serie de fotos proyectadas en la pared que le sirvió de pantalla, realizó una ceremonia de despedida, llevó flores y veladoras y dio cuenta de sus cualidades. Nos fue relatando lo inteligente, encantador y solidario de su amigo. Era músico, poeta y estudiante. Terminó al grito de "¡no más muertes de estudiantes!"

Cartografía existencial. Llevó un proceso de duelo, se casó y tiene una niña.

7. Familias. Otra profesionista, psicóloga joven de сірам (Centro Integral para la Mujer), realizó un espectáculo con piedras diversas en el piso del escenario, y reuniéndolas por sus tamaños y similitudes nos mostró cómo las familias eran así de diversas y diferentes. Para terminar con la pregunta al público de qué les pasaba si no eran regadas. "Se rompen, se resquebrajan" - le contestaron. "Si" -nos dijo-, mientras les echaba agua a algunas, "se convierten en polvo", una metáfora sobre el cuidado que tiene que haber en cada familia hacia sus integrantes.

Cartografía existencial. Se casó y tiene un bebé.

8. Perlas de cultura. Verónica, ama de casa, se presenta elegante, arreglada y junto a una mesa con una gran pecera de cristal que contiene cuatro grandes piedras pulidas en forma de diamante y de colores diferentes. Empieza hablando de los buenos talleres que ha tomado gracias a los beneficios de su credencial de INAPAM, de los recorridos y cursos de historia tomados en el centro histórico. $Y$ nos pregunta al sacar una joya del recipiente, “¿conocen el edificio de...?”, nombrando cuatro grandes joyas arquitectónicas del centro histórico.

Cartografía existencial. Después de continuar sanando con talleres su corazón por la muerte de su marido, sigue tomando cursos en el Centro histórico. Ella asistió al siguiente proyecto de Corazón Seguro en la Alameda.

9. Hace seis meses. Juanita era trabajadora de limpieza y estaba enferma del alma. El día de la presentación fue muy arreglada, se abrazaba de un rebozo blanco que no soltaba. Como siempre en los ensayos, quiso decir lo que le había ocurrido en el diciembre pasado, después de la muerte de su amado hijo. Y así lo hizo. 
Dio cuenta, entre lágrimas y sin bajar la cabeza, que había sufrido una violación colectiva."Eran tres, bajé del camión para dirigirme a casa y me jalaron a un terreno baldío, hicieron lo que quisieron conmigo. No me levanté en un día, en dos, en tres... ni comí, ni me lavé. Así llegué con mis hermanos... como zombi, no les dije nada... hasta que ellos preguntaron." Por su performance, al final de la presentación, alguien del público pudo tomar el micrófono y denunciar el acoso de un tío en su infancia.

Cartografía existencial. Juanita participó en el siguiente proyecto, en Corazón Seguro, integrada al grupo del performance (había el de foto y el de instalaciones) y como pieza se presentó con una actitud lúdica dentro de una fuente de la Alameda con una sombrilla, como bailando y chapoteando. La última actividad fue participar en el video del trabajo final del ccc (Centro de Capacitación Cinematográfica) "Baños de vida", sobre los baños de vapor públicos, a los que asistían regularmente algunas de las trabajadoras de la limpieza, a quitarse del cuerpo y de sus sentidos "el olor inmundo de la basura", así decían. Habló de su vida frente a la cámara, de la enfermedad en el hospital y muerte de su "adorado hijo", de haber pedido caridad para vivir por lo caro de los medicamentos, confesó haber amado a su hijo y, por él, haber comido de la basura. Agradeció a los proyectos por estar viviendo "todo lo que Dios no le había dado". También en el film se le podía ver discutiendo. Una de sus compañeras comentó que "Juanita murió de un coraje con el jefe. De un paro diabético". Nunca tuvo otro proyecto más que sobrevivir.

IO+j Ya no! En este performance Gabriela, trabajadora del barrido cuenta por qué entró a este trabajo. En la escena se le ve lavando en una tina de agua metálica con una tabla de lavadero portátil. Ella está en cuclillas y tiene a un bebé envuelto en cobijas a su lado y mientras hace su labor está hablando y dirige su mirada hacia arriba, diciendo enojada “ ¿¿qué? ¿qqué no hago nada? Pero si cuido a tu hija y lavo tu ropa y... ¿que ya te vas a comer con tu mamá porque cocina mejor que yo?, ipues vete $($ c...)! ¡ Ya basta!". Se levanta, se pone un uniforme que estaba en el piso del escenario, toma en sus brazos a su bebe y sale de la escena diciendo: "yo me voy a trabajar y ique me paguen!"

Cartografía existencial. Tiempo después envió a cada una invitación para el bautizo de su hijita y en otra presentación llevó a su nuera jovencita embarazada, como de siete meses, quien se subió al escenario y emocionada comentó que, a partir de la performance de su suegra, ella tampoco iba a permitir que la maltrataran. De Gabriela me informaron que "se salió de ese trabajó, se peleó, andaba enojada".

II. Nunca esperes más. Verónica, trabajadora de la limpieza, sube al escenario y llena de indignación dice: "durante diez años te aguanté, borracho, mal viviente, 
desobligado, violento, ¡ya no más! Me maltrataste a mí y a tus hijos. ¡Ya no más!”, y lo dice al mismo tiempo que se quita un suéter bajando el cierre y la cremallera de una falda de mezclilla, quedándose en una camiseta larga y un mallón ajustado. Así sale de escena, digna, derecha, con la mirada puesta en el horizonte, con lágrimas en los ojos, y como si recuperara su cuerpo al liberarse de la indumentaria que la amordaza, declara: "ya voy a ser yo."

Cartografía existencial. Continuó en el trabajo siguiente de Corazón Seguro. Se separó de su pareja, vive con sus hijos y sigue trabajando en el Centro histórico. Tiene un novio indigente que la trata muy bien, ella le da dinero.

12. La injusticia de la justicia. Irma, conocida como "la coño", siempre reivindicando su sangre tabasqueña, también trabajadora del barrido, entró en escena apoyándose en su bastón. Como mobiliario decidió poner una mesa con un libro abierto, la Constitución y una balanza que simboliza la justicia. Tomó la palabra y contó, con lujo de detalles, cómo su hijo había estado en la cárcel durante los seis meses anteriores, argumentando sobre la injusticia del monto de la caución asignada, dando cifras exactas de más de 100 ooo pesos cuando ella y su hijo ganaban 3000 pesos cada uno. Preguntando al público con todo y la mirada, "¿de dónde vamos a sacarlo, señores y señoras?" "Tanto dinero! "Mientras rateros de corbata salen por palancas o no se les detiene". Ya en una entrevista decía que no iba a parar "hasta conocer a todos los de arriba para denunciar lo que ocurría".

Cartografía existencial. Sigue en el barrido. Ahora se desplaza en motoneta, ha tenido problemas de salud, está terminando la prepa abierta y desea inscribirse en la carrera de Derecho.

\section{El re-encantamiento del mundo y la experiencia del performance}

Después de ver en el video nuevamente parte de la experiencia de los talleres y performances videograbados es claro que cada caso de vida de las mujeres-actoras involucradas en esta comunidad es complejo. Resolverlos es muy difícil con actividades de talleres de tres o seis meses, tiempo en el cual se desarrollaron los dos proyectos. No era la idea. El performance colectivo efectivamente llevó a las participantes y a los espectadores a crear ambientes, experiencias contagiosas que tenían un efecto en nuestro cuerpo, se cambiaba de estado y nos conmovíamos. Fue un ejercicio tonificante para las emociones y su reflexión. Más allá de la catarsis que a veces se presentó, la pedagogía fue la empatía, lo humano, tejer vínculos y lazo social. Darnos cuenta de que somos iguales y de que cada vida, por sencilla o difícil que 
sea, vale la pena vivirla. Ciertamente se lograron experiencias límite, como pequeños rituales que inspiraban respeto en la escucha por el tramo de la vida mostrada, donde el esfuerzo de cada una por ser era bello. Fue una experiencia estética donde se intentó expresar, no representar, algo con todo y el cuerpo, compartir algo de lo vivido. Aquí recordamos el desarrollo de la empatía para la cultura de la democracia que sugiere Martha C. Nussbaum (2014:453) en su libro sobre las emociones y la política. Sobre la poética de la justicia como sanación.

\section{Modo de producción de los performances}

Poner el cuerpo, producir conocimiento con el cuerpo, ${ }^{9}$ activar la percepción, abrir la sensibilidad, crear ambientes estéticos envolventes de afecto, prepararnos a traer al cuerpo presente recuerdos, vivirlos, no representarlos. Esa fue la estrategia.

Sentir, pensar, comprender y $\operatorname{actuar}^{10}$ cada una y enfrente de todas. De adentro hacia afuera producirnos frente al colectivo y proponer cambios. Empezar por vivirlos ahí mismo, en presencia. Primero sacar el cuerpo con las razones del recuerdo y hacer el cambio, un pequeño desplazamiento decisivo con todo y el ser. Hacer de lado las herramientas del trabajo, por ejemplo, la escoba o la laptop y terminar en otra acción emancipadora, liberadora, en un tiempo de excepción. Disponer al mismo tiempo el espacio con algunos objetos y habitar nuestros cuerpos de otro modo. Transformar el espacio donde nos alojábamos en un lugar, ${ }^{11}$ habitándolo ayudadas por atmósferas amables, po-éticas donde vivir esos cambios con emociones. Sacar lo vivido y actuar con otras intenciones, con sueños y demandas (muchas mujeres se referían o anhelaban estar mejor, obviamente).

Experimentamos vivencias de enojos, miedos, frustraciones y reímos y lloramos juntas, atravesábamos emociones y creamos comunicación afectiva (intersubjetividad), sin negar la materialidad del cuerpo. ${ }^{12}$ Así, nos sentimos parte o, más bien,

9 Este tema epistemológico lo trabaja actualmente Marisa Ruiz Trejo $(2015,2016)$ en la producción de conocimientos alternativos con metodologías que retoman al cuerpo.

10 Casi la lógica del método científico de las ciencias duras.

11 Heidegger, en su obra Ser y tiempo, trabaja el sorge, la cura, como transformación ontológica del cuidado de sí y del entorno.

12 Para Maite Garbayo (véase nota 22): la intersubjetividad funda una realidad específica y la define como elemento sustancial del transporte amoroso, surge cuando al afectarse ambos sujetos (donde el objeto es sujeto) se influyen en una relación donde existe el cuerpo y el afecto. Argumento dado en la presentación del seminario "Intersubjetividad, transferencia y einfüblung. ¿Cómo pensar desde los feminismos en una estética que pase por el cuerpo ¿En una estética de los afectos y del transporte amoroso?", en el IIE, UNAM, agosto 2016. 
fundábamos una "colectiva" que nos abrazaba, contenía, lejos de nuestra vida cotidiana. En medio de pequeños rituales hacíamos los cambios. Al final de cada tarde compartíamos la comida, saciando otra hambre con charlas, escuchas atentas sobre trazos de nuestras vidas, delineando otros ahí mismo. Íbamos cambiando, sintiendo un nuevo cuerpo. Realizábamos acciones con-juntas, arte participativo (Bishop, 2016: 13I), como decíamos antes, caminar por el Centro histórico con los ojos cerrados, de la mano de otra compañera como guía, o llegando todas las 26 participantes (policías, trabajadoras de limpieza, amas de casa, estudiantes, gestoras culturales) a la plancha del Zócalo disfrazadas en lo opuesto de lo que generalmente éramos, esa fue la instrucción: y llegó la policía como ama de casa, otra de mujer que pedía limosna, de prostitutas, de maestra, etc. En esas atmósferas lúdicas, solidarias, de apertura de los sentidos, una a una nos comprometimos en lo íntimo de nuestras cavilaciones y ayudadas por esa energía grupal de los actos "animativos", como los nombró Diana Taylor, ${ }^{13}$ a hacer cambios en nuestras vidas que empezaron en ese encuentro entre el cuerpo y la conciencia. ${ }^{14}$

Empezamos a hacerlo al encarnar la ciudad (Sennett: 2003) con nuestros trayectos, que resultaban llenos de olores, sabores, recuerdos del tacto y amistad. Se exaltaban la percepción, la vivencia interior, la introspección y salíamos de los muros del cuerpo, de esa piel más fuerte que las piedras físicas y subjetivas de imposiciones edificadas durante siglos. Resignificamos el espacio del centro al caminar diferente, hacia adentro, de otra forma, y nos desterritorializamos al hacer un territorio - de paz- con nuestros cuerpos con vida propia dentro de la gran ciudad. De cada una de las sesiones con Lorena Wolffer salíamos activadas, y se produjeron los pequeños giros de tuerca, teniendo como resultado las 26 piezas individuales que se expresaban en metáforas casi poéticas por sus títulos: "Así no", "Ya basta", "Luz power", "Re-formada”, “Cómodas?”,"La justicia de la injusticia”, etcétera.

El sentimiento de empatía (felling into, el einfhü lung) ${ }^{15}$ acompañó cada presentación, donde el tiempo, el espacio y el movimiento dramático se construyó de

13 Diana Taylor en la conferencia "La política de la presencia", que se llevó a cabo en el Auditorio de la Unidad de Posgrado de la unam, Ciudad de México, in de octubre 2016.

14 Tema que sin duda fue abordado por la Fenomenología de la percepción de Maurice Merleau Ponty (1994).

15 El concepto de Einfüblung es traducido del alemán como empatía, término propio de la estética alemana del siglo xix desde el que se pensaba que el sujeto era quien investía a la obra de arte con una parte de su ser. La forma como se utiliza en este texto parte de la reformulación hecha por Vernon Lee y Clementine A., en I887, para quienes el término remite más a una trascendencia de la dualidad entre sujeto y objeto, en tanto ambos logran reorganizar sus subjetividades en el encuentro con el otro. 
sensaciones, memorias y pensamientos con recursos sonoros o imágenes y objetos que llevábamos todas, cada miércoles, al pensar durante la semana en los trabajos propios o de las otras (balanzas, lavaderos portátiles, flores, velas, vestidos, música, aretes, pintura de labios o una pintura al óleo en un lienzo, imagen de un cuerpo gozoso de mujer, adecuada para alguna pieza).

Logramos cambios extensivos a la vida cotidiana, con el nuevo cuerpo y su energía autoproducida a través de esos ejercicios autopoiéticos; se nos salía por los poros para agujerear los discursos de opresión y subordinación fabricados y operados con resentimiento, por ignorancia o autoexploración en el trabajo, en la casa, en las familias, en los trayectos del transporte público, etc. Reunidas cada miércoles durante tres meses, entre los muros anchos del atrio de la antigua iglesia (que en la Colonia, según las leyendas, emparedaba en vida a novicias embarazadas, seguro por algún cura), y que ahora funge como Museo de Arte Contemporáneo "El ex Teresa", todas queríamos cambiar al mundo, empezando por el nuestro, acabar con las diferencias, hacer justicia (Norandi, 20I0: 43), recoger nuestros pedazos, limpiarlos, librarnos de los corsettes femeninos incómodos, muchas veces autoimpuestos por la historia y vividos como armaduras, y seguir con más decisiones sentidas, conciencia, voz propia, libertad y dignidad, caminando la vida.

\section{Cuerpos sujetados}

Antes de los talleres, durante la primera presentación, respondimos desde nuestro ser y estar ${ }^{16}$ ¿cómo estábamos? Aparecían los cuerpos domesticados. La mayoría lo hicimos desde representaciones que incluían a la mujer en el trabajo y su salud, pero rápidamente entramos a terrenos donde lo privado del cuerpo se hacía público. Había reclamos frente a una condición degradada, con heridas profundas y en algún caso ya con deformaciones ontológicas al sentir que su destino era la mala suerte, sin poder posicionarse desde sus posibilidades de acciones para el cambio. La empatía nacía al estar juntas, escuchándonos. Se preparaba el espacio de aparición desde la escucha respetuosa, la conversación de verdades, muchas veces crudas, lo cual nos afectaba, nos conmovía; se construía un transporte amoroso (Garbayo, 20I6b) con el cual, más adelante, con unas carcajadas colectivas, un buen pan y nutridas con esa energía, le dábamos la espalda a esos altares antes sacros e inmundos, y operaba

16 La definición de cuerpo de Elsa Muñiz es muy adecuada para este trabajo. El cuerpo es un continuum biológico-cultural complejo, donde se manifiesta el ser. 
un acto de desafío. Se transformaban las penurias, injusticias y las humillaciones en expiaciones, un espacio de reparación y de demandas. ${ }^{17}$

Sería difícil la desidentificación de imágenes de dolor, teníamos que drenarlo, éramos sujetos vulnerados, pero lo lograríamos al entrar en las emociones de solidaridad para muchas veces darle contención a la rabia y poder diseñarnos desde la indignación, la reflexión y la complicidad, el gozo, ese era el propósito colectivo que se iba fraguando con los performances. Una forma de compromiso encarnado con las otras, que nos llevaría más allá de las formas y modos restringidos de ser y operar, aunque fuese por un momento.

Para Diana Taylor "las prácticas del performance cambian tanto como su finalidad, a veces artística, a veces política, a veces ritual” (20I2:6I) ${ }^{18}$ Esto comprende actos de tipo activismo social.

\section{El cuerpo del conocimiento}

En el cuerpo real de cada participante se observaron las condiciones de producción de lo emocional como político. Es ese el cuerpo real y sus motivos lo que nos llevó a una reflexión sobre las implicaciones políticas en las vidas personales, por tener razones públicas. A una comprensión de las relaciones de poder que se entablan tanto en lo profesional como en lo personal, en todos los mundos de vida. Lo anterior se llevó a cabo con otros lenguajes estéticos. Trabajamos lo emocional como político, dimos con condiciones de producción de nuestros asuntos y lo comprendimos desde las entrañas. Pero pretendimos no solo quedarnos en la comprensión crítica y en el enojo, sino que nos llevó a actuar y producirnos diferentes. Trabajamos de manera representacional la emoción y desde la economía material y simbólica, por cuanto nos costaban afectiva y energéticamente los comportamientos. No podíamos quedarnos en la victimización, o solo en la afirmación, teníamos que caminar hacia la resistencia. Al desentramar la reproducción social con nuestros anhelos, enfrentábamos la existencia de una política estructural de las emociones. Llegamos a un conocimiento más allá de las disciplinas, con otros lenguajes para estudiar al cuerpo, más bien para producirlo, y que tiene que ver con cambios paradigmáticos y epistemológicos en la construcción del conocimiento actual.

17 Véase Mayer, 2010.

18 Lo anterior lo dice haciendo una revisión del trabajo sobre la performance latinoamericana de Jesusa Rodríguez, Liliana Felipe, Maris Bustamante, de Antonio Prieto, de Rose Lee-Goldberg, de Mónica Mayer, de Josefina Alcázar y Fernando Fuentes y Emilio Tarragona. 


\section{Del cuerpo de la protesta a los cuerpos manifiestos: un giro colectivo}

Lorena Wolffer es el cuerpo de la protesta al recordar-nos a las asesinadas de Juárez, uno de sus trabajos emblemáticos, donde pone el cuerpo. En este otro trabajo performático de Cuerpos manifiestos se compromete con más mujeres para recordar su vulnerabilidad y su sometimiento, saliéndose del discurso de la representación comprensiva y proponiendo otros lenguajes para que los cuerpos hablen a través de sus emociones. Es el cuerpo de la empatía.

Se alía con las "bicentas" ${ }^{19}$ de Territorios de cultura, quienes decíamos, ya venían trabajando en el Centro histórico con mujeres en trabajos precarizados, para llamar casi exasperadamente la atención ante demandas insatisfechas como el derecho a vivir una ciudad de la cultura, de la creatividad, la imaginación, de los saberes, más que de la disciplina del cuerpo, donde muchas de ellas se encuentran en un estado de supervivencia y frente a políticas públicas rebasadas, deshumanizadas.

El proyecto con ellas/nosotras se crea en el horror y para que se nos olvide que no debemos portarnos como manda la tradición y menos el discurso católico conservador, que las mujeres nos pertenecemos a nosotras mismas, no a la familia ni a los hombres ni al Estado y, lo más importante, que somos las que hacemos a la ciudad en nuestros recorridos llenos de emociones y no al contrario: construimos así, por momentos, más bien pausas en el trabajo tan necesarias, planteadas por Boltanski y Chiapelo en su libro El nuevo espíritu del capitalismo (1999). Por una ciudad liberada por proyectos que la encarnen.

Las piezas de los performances en las presentaciones fueron sobre el cuerpo de "la conciencia", sometiendo a juicio en la plaza pública al cuerpo de "la injusticia". El mostrarnos en los recorridos y en las presentaciones a los públicos cómplices y sintientes fue una vivencia conmovedora que permitía experimentar, emocionados todos (también los espectadores/participantes), que ante la miseria moral caminan cuerpos de esperanza por la ciudad, "desde tener más emociones justas" y una política cultural del amor de la que habla Sara Ahmed (2015:287).

En este trabajo Lorena expone el cuerpo, el suyo, a la indignación, a la escucha y al acompañamiento, para luego animarnos a cada una a producirnos, a dar las vueltas de sentido, de manera colectiva, con sentimientos y emociones. Ofreció su destreza utilizando casi el método de las ciencias duras, para la creación de una

19 Mote con el que se nombraban las cuatro integrantes de la colectiva de Territorios de Cultura, por el festejo del bicentenario de la independencia de I8Io acaecido ese año. 
nueva naturaleza, observar, sentirpensar ${ }^{20}$ y resolver con actos performáticos y la performatividad desarrollada por Butler (2002: 19). Se tenía en claro que el poder moldea cuerpos y emociones y acalla determinados cuerpos, haciendo pasar por individuales problemas del orden de lo social, de estructuras que hacen que nos sintamos más culpables que víctimas, por ejemplo, ante problemas no solo de violencia sexual y de género, sino también en el empleo, en la vida intrafamiliar, problemas del orden de la salud pública, etcétera.

Lorena sabe muy bien que los cuerpos también se hacen, son productos de aprendizajes que se moldean a través de las emociones, por ejemplo, el miedo y la falta de merecimiento de servicios en la ciudad. Miedo para reunirnos y porque nos alejan privatizando espacios, y hacen valer a algunos cuerpos más que a otros. Esto ocurre porque la lógica del consumo, y no nada más la del espacio urbano, nos consume, transforma nuestro cuerpo, como recurso sensible, subjetivo, en valor de cambio. ${ }^{21} \mathrm{El}$ trabajo en conjunto de Lorena y las bicentas, y nosotras, las mujeres que participamos, da cuenta de lo que está detrás de esta economía material y simbólica, una política estructural de las emociones inscritas en el cuerpo, y que se intentó desregular de la reproducción social, aunque fuese por momentos (véase Garbayo, 2012).

Es por ello que, con la performance feminista realizada, de implicaciones políticas, se ensayó dar voz a esos cuerpos de mujeres, que son los cuerpos de la injusticia en estos tiempos del horror, donde son uno más de los tantos "cuerpos de los condenados" de los que habló Michel Foucault en el capítulo del mismo título de su libro Vigilar y castigar (2002: 6). Lorena mantuvo una actitud crítica hacia el panorama sociopolítico, de ahí su concepción del performance como arte de acción, arte de la resistencia.

\section{El público en estas piezas de performances}

Cada presentación fue una premier, un estreno, era diferente y la participación del público también.

El primer público fuimos las propias participantes que vivíamos los procesos con las compañeras a lo largo de los talleres, y observábamos, como ya dijimos, el trabajo de Lorena. Tuvimos varios escenarios de presentación y ella siempre fue

20 Este concepto fue abordado para la investigación por el sociólogo Fals Borda, véase su aplicación en el trabajo de Andrea Bolvillani (2013).

21 Francisco Castañeda Rodríguez-Cabo (1983) desarrolló una tesis interesante sobre la ley del valor y la subjetividad como parte de ella, como recurso a reconocer. 
quien invitó el público a participar. Lo hizo de diferentes maneras, de acuerdo con el contexto de la realización escénica.

Invitaba siempre a expresar lo que a ellos, los espectadores, les había ocurrido, cómo se habían sentido afectados, en busca de que no solo se explicitara la relación dialéctica que se producía de tesis y antítesis y síntesis entre lo que presentaban las participantes con los espectadores, sino también al dar espacio para que se expresara con todo y el cuerpo emocionado, la comunicación afectiva, la construcción de la intersubjetividad. Más allá de lo dialógico.

En el ensayo general nosotras mismas fuimos el público, junto con los familiares. Todos(as) colaborábamos, hacíamos observaciones de cómo podíamos mejorar. En la premier del Centro Cultural de España, al final el público externó sus impresiones, Lorena abrió y convocó un espacio para la participación. Nos trasladamos a la terraza y algunas personas del público externaron historias desde casos de abusos del cuerpo, incluso hombres conmovidos por los casos presenciados preguntaban qué hacer.

En las siguientes dos presentaciones la instrucción fue otra: en la plaza pública del Zócalo cada una dijo la razón de su pieza frente al público de transeúntes asistentes a la feria; lo que querían representar y la participación de los espectadores fue mínima.

En la Casa de la Primera Imprenta, cada una iba subiendo al espacio escénico y ponía una vela en donde empezaba el escenario, al mismo tiempo que pasaba al micrófono diciendo brevemente, casi con una frase, el nombre de su pieza, de qué había tratado y qué le había dejado, o con lo que se había comprometido al hacer el performance, casi con una frase que se transformaba en ritual, en acto de esperanza colectivo. Después caminaba por el escenario y se colocaba con las otras compañeras, formando un semicírculo. Desde el inicio Lorena invitó a la gente, a los espectadores, a dejarse afectar y a subir al escenario y a que tomaran una vela y la palabra; también les pedía que lo hicieran en cuanto escucharan algo que resonara en ellos, alguna situación que quisieran comentar.

Del público invitado, conformado por muchos acompañantes de las mujeres participantes, solo plantearé dos participaciones, dos casos. Un alumno de antropología de la Universidad Autónoma Metropolitana-Iztapalapa subió al escenario y reconoció a su madre, diciendo que también era trabajadora de limpieza, como muchas de las mujeres participantes del performance, y que los había sacado adelante después de que su padre partiera para Estados Unidos.

Otra chica embarazada subió al escenario conmovida y dijo que como su suegra, a quien acababa de ver y oír, ella también se comprometía con ella misma a no 
permitir que su pareja le pusieran la mano ni el pie encima. Al parecer se daba una relación de sustitución; muchas veces los sin cuerpo, por tener un cuerpo domesticado, los carentes de voz durante tanto tiempo, la tomaban, la alzaban, y de entre el público que lograba sentirse afectado, sentir en ese momento y recordar algo de su propia vida, se dejaban tocar por los afectos y traían al cuerpo vivencias, y gracias al cuerpo en movimiento de una de las compañeras, quien giraba de un cuerpo a otro, del traslado sufrido en presencia, surgían otras pieles, cuerpos donde se inscribían los mismos sueños y las demandas con cuerpo presente, puestos de manifiesto.

Para Maite Garbayo, ${ }^{22}$ una ruta para explicarnos lo que ocurre en estos actos estéticos es a través de algunas reflexiones de Lacan (1977, 2006), sobre Bertold Brecht elaboradas por Ruth Berlau (1995) y Freud (2014). La relación a tres que trabajó el primero, hace referencia a cómo alguien sin cuerpo (ausentado por algún trauma o dolor) lo puede sentir en espejo, gracias a la presencia de otro cuerpo, arrobado a su vez por otro. Y ocurre lo opuesto de lo que propone Brecht con su teatro crítico, donde formula procedimientos para generar la toma de distancia y poder pensar, como teniendo miedo de despertar las emociones. De acuerdo con la reflexión sobre el giro afectivo (Clough, 2010) y sobre el giro emocional trazada por Sara Ahmed (2015:9), Garbayo ${ }^{23}$ plantea lo contrario al binarismo mente-cuerpo: en los actos estéticos, para generar una interacción, se entra a ellas, a las emociones a través de la transferencia. Estas son provocadas por el objeto que siempre es sujeto, y uno se deja afectar y se produce una vuelta de tuerca, produciendo-se (en - y) acciones diferentes. El tercer caso, el más emblemático y clásico, es el de la histeria de Dora, arrobada, extasiada, al ser tomada por las emociones frente al cuadro de la virgen, caso del que aprende mucho Freud (1988) sobre las emociones sujetadas en el cuerpo, y tema retrabajado por Didi-Huberman (2007) al analizar la estética de las imágenes fotográficas de las mujeres internadas a finales del siglo xix en el hospital psiquiátrico de la Salpêtrière de París, en su potente libro de crítica a la genealogía (y dispositivos de fabricación médica de Jean Martín Charcot), sobre la invención de las histéricas, quienes, se sugiere, querían ser miradas, aunque fuese

22 Mayte Garbayo es doctora en historia del arte y recomendó la lectura de los textos de estos autores en el curso de posgrado "Seminario de cultura visual y género: estéticas, cuerpos y afectos", que impartió en el IIE-UNAM, junto con la colectiva Manu(El) (LA), en el MUAC y al cual asistí en agosto-noviembre de 2016 .

23 Argumento planteado en su curso (véase nota anterior) como una de las tesis que desarrolla en su proyecto de investigación posdoctoral "Intersubjetividad y transferencia: hacia una estética de lo incalculable" en el IIE, UNAM, septiembre de 2016. 
por los ojos del médico, como objeto de sus investigaciones (mirada clínica un poco siniestra).

\section{De los performances en el espacio público a la ciudad encarnada}

Al hacer uso del espacio público lo hicimos nuestro, su arquitectura fue nuestro cuerpo. De acuerdo con la urbanista Jaqueline García Bautista ${ }^{24}$ la arquitectura disciplina a los cuerpos tanto como las instituciones, y en esta geometría del dispositivo, el sentido y los recorridos con los sentidos son invisibles. En el trazo de las calles de la ciudad el movimiento tiene que verse, pero el poder no solo se ve, se siente, por ello fueron muy interesantes las líneas deluzianas de fuga de deseos, (Piedrahita, 2014: 16) planeadas en el performance de cuerpos manifiestos en los espacios del Centro histórico. La ciudad fue espacio coreográfico del devenir. El andar se transformó en energía en movimiento, no lineal sino circular, en giros, fue caminar sin líneas trazadas, con la existencia encima.

En esos espacios abiertos ${ }^{25}$ la ciudad apareció como un gran escenario y fue nuestro cuerpo el que la hacía, como en un ir y venir donde la habitamos y ella nos habitó. Al dejarnos llevar por los recorridos de olores, sabores ancestrales, sensaciones, al pasar el tacto por los objetos predilectos de alguna compañera, al caminar por espacios y recovecos mostrados por cada una a la otra, con los ojos cerrados, y de acuerdo con rutinas personales o creativas en ese momento, donde la improvisación y el juego existían, delineábamos la ciudad de los afectos, que tiene un antecedente reflexivo desde los años setenta con Jean Jacobs en su libro Muerte $y$ vida de las grandes ciudades. Los objetos se transformaban en sujetos. Al producirnos en los diferentes espacios y mostrarnos, de acuerdo con estados de ánimo, generábamos contra-espacios, espacios liminares en la ciudad ocupada, por donde transitar la vida; privilegiamos una comunicación intersubjetiva para la creación de nuevos gestos no repetitivos. Con el juego y el afecto escapábamos al poder que controla los modos de comportamiento, o más bien subvertíamos el orden, re-significábamos la norma: escapábamos al comportamiento aceptado en ese espacio de

${ }^{24}$ Se refirió a esto en el curso que dio, en la sesión del III Diplomado Cuerpo Descifrado, "La urbe encarnada: un devenir entre el cuerpo y la ciudad", UAM-X, 22 de octubre de 2016.

25 Nora Rabotnikof (2008: 38) reflexiona sobre cómo el espacio público tiene al menos tres acepciones: público-estatal, público-social y público-cívica. A partir de estas características, el espacio abierto se encuentra seriamente condicionado, no solo por la arquitectura. 
control del cuerpo y de su capacidad expresiva gracias a nuestro movimiento, como en redes de esferas (Quesada, 2013: 26).

$\mathrm{Al}$ ir presentando nuestra apropiación de la experiencia de la ciudad a alguna compañera, durante estos recorridos éramos más que ciudadanas, éramos citadinas, al considerar las características de género, edad y raza primero que las de clase, nivel de estudios, etcétera.

Por eso digo que fue un arte de la resistencia, pues al devenir el cuerpo en la ciudad, esta apareció como ciudad de los umbrales, planteada por Stavrides (2016: I5-I6), transformándonos ahí mismo. La ciudad y sus espacios no nos excluían, no lo permitíamos, juntas recuperábamos el cuerpo como lugar, la subjetividad como recurso y la ciudad de los afectos.

El espacio público se hace público en cuanto lo usas, y la gente sometida es usada si no está en la construcción de sí misma, como lo reflexiona Hanna Arendt en su libro sobre La banalidad del mal; al estar solo habitada, por ejemplo, por la necesidad o el consumo. Así se deja al valor de cambio la exclusión/inclusión de las personas de las ciudades. La idea subyacente era exigir una política de la sustentabilidad de las personas, no la de las ciudades, gracias a que habitábamos nuestros cuerpos y amarrábamos los espacios con nuestra piel. De esta manera: entre prácticas performativas, estéticas, con coreografías, y en abrazo colectivo, cuerpos precarizados y desterrados de agencia, por condiciones de género, trabajo, raza, alzaron la voz.

\section{Cuando hicimos de las calles una ciudad creativa}

Estas acciones estéticas en la ciudad nos recuerdan que la gente es parte de ella. Para Stephanie Varela ${ }^{26}$ la ciudad se vuelve un espacio de subversión o de disputa a partir de sus propias reglas. En esto sigue a Chantal Mouffe y a Judith Butler, quienes aluden a la manera en que la práctica artística cambia el entorno y cambia al propio cuerpo, ya que resistir también reside en poner el cuerpo en el centro. Stephanie Varela, en la misma comunicación, menciona a Diana Taylor, quien sigue la propuesta de J. Austin sobre "la palabra como acción" (20IIः 16), elemento determinante que le permite a Varela relacionar la interacción del cuerpo con el espacio: el cuerpo también habla con su presencia. Desde el trabajo antropológico de Víctor Turner, en su libro, El proceso ritual de 1988, se puede decir que el acto performativo de empoderarse por medio de las frases brinda legitimidad ante otros, al portar

${ }^{26}$ Comunicación personal. 
la voz y desarrollar actos performáticos a través del cuerpo. De esta manera, las mujeres en Cuerpos manifiestos hacen de los escenarios de la ciudad, donde se presentaron o más bien se produjeron, incluyendo las calles, un lugar que visibiliza los desacuerdos, los problemas de género principalmente, pero también permiten pensar en cómo habitamos el espacio y cómo fue habitado hasta entonces (De Solà-Morales, 2008; Lindón, 2007).

Asumir que al cuerpo también lo hace el lugar, y al contrario, es avanzar un paso para exigir respeto. La experiencia de los recorridos del performance de entre las calles que rodean al Zócalo, la propia plancha del Zócalo, las plazas y los edificios históricos donde estuvimos y nos presentamos, es devenir el cuerpo. Lo anterior lo señaló Jaqueline García Bautista, ${ }^{27}$ al decir que es la primera arquitectura a la cual hay que adaptarse y adaptar los lugares a esos cuerpos, que implica tecnología, cultura y un nuevo humanismo. Un cuerpo colectivo es el que tiene que tomar la voz ante la criminalización del cuerpo de mujer, al que se suman todos los cuerpos. Es desde ese cuerpo de mujer en resistencia, de acuerdo con Butler (2015), ${ }^{28}$ que hay que re-significarlo, pues hay que aprender a ser de nueva cuenta vulnerabilidad y resistencia.

Es David Le Breton (2002) el que dice que las ciudades no tienen el tiempo de la naturaleza, se ha alterado su ritmo. Pero con estos actos performativos, con lenguajes estéticos donde está vigente el giro afectivo del cuerpo, en este caso de las mujeres en la ciudad (Garbayo, 20I6a), regresan otros llenos de corporalidad y territorializaciones, ficciones por la paz, nuevos significados y deseos de otra naturaleza vulnerada y en resistencia.

\section{Conclusiones}

El futuro se fue haciendo a lo largo de la acción, y la ciudad tomó la forma de cuerpos de mujeres". El performance y los actos performativos y la performatividad que se fueron dando crearon una pausa y un espacio para habitar el cuerpo de otra manera, muchas veces incierta e inestable, para inventar de manera lúdica e improvisada un cuerpo presente. ${ }^{29}$ Ciudad encarnada por ellas/nosotras mismas en la ciudad como

27 Véase su presentación en la nota 23.

28 Conferencia de Judith Butler "Vulnerabilidad y resistencia revisitada", 23 de marzo del 2015, impartida en sala la Nezahualcóyotl, unam, México.

29 Como lo expuso Diana Taylor en la conferencia “La política de la presencia”, a la que asistí, y que impartió en el Auditorio de la Unidad de Posgrado de la unam, Ciudad de México, ir de octubre 2016. 
lo dice Patricia Ruvalcaba en su reportaje de la presentación (2010). Al igual que lo expresa Lorena Wolffer en su pieza premiada "Espacios de excepción", realizada en la ciudad de Querétaro en 20I4. Mujeres juntas tomando un momento de respiro en estos tiempos atroces, de urgencia, por la inoperancia de los discursos normativos y de las leyes de protección para las mujeres.

Los talleres de producción de las piezas de performance generaron un espacio de juego donde fraguar procesos liminares, pequeños cambios en colectivo. Ello generó que al menos durante ese tiempo se diera un activismo en las vidas cotidianas de las mujeres participantes, con pequeñas autoproducciones, improvisaciones, y que dieran vueltas de tuerca en medio de la indignación, afirmando-se, y creando futuro. En la medida en que avanzábamos se provocaban nuevas formas de socialización, usos comunes y autogestivos del espacio, la creación de sueños de lo imposible.

Como piensa Benjamín Arditi, ${ }^{30}$ el trabajo de performance es virtuoso porque es como un gran teatro de lo posible. En el caso que nos ocupa, las mujeres fueron haciendo ensayos sobre su vida, al pensar y actuar sobre cómo vivir el presente, cómo amar, cómo enfrentar el desamor, la contingencia, con ideas de cómo se deseaba vivir al ir sedimentando su futuro. En este sentido, la ficción sirve a las ciencias sociales (Gómez, 2015ः 3I). Todos los días que nos reunimos se vivieron como una premier al construir vivencias especiales en el Centro histórico de la ciudad. Sin mapa de navegación, se surcaron rutas propias donde el faro era interno e individual y para descubrirlo ayudaba el afecto, el enojo, la energía del colectivo, el estar juntas.

Por ello, de acuerdo con Arditi en su artículo virtual "Las insurgencias no tienen un plan: ellas son su propio plan: performativos políticos y mediadores evanescentes" de 20I3, lo que está realizándose, más que seguir un programa político y un plan, es una política del cuerpo presente. Un sujeto y un lugar de enunciación que sale a las calles y dice, en este caso, iya basta!, expresando la emoción de nuevos colectivos (Appadurai, 2007: 63). Es algo que sin duda logró el proyecto artístico y cultural de los performances de mujeres de Cuerpos manifiestos dirigidos por Lorena y la colectiva feminista, Territorios de cultura para la equidad, a cargo de Pilar, Aurora, Yanina y Maricarmen, con nosotras y en alianza con otras artistas, organizaciones, dependencias del Centro histórico, el Centro Cultural de España y aliados y aliadas diversos.

Fue una fecunda forma de respuesta social frente a los tiempos atroces por tantas mujeres asesinadas y violentadas. Ecos del luto humano que vivimos y también

30 Comentarios de Benjamín Arditi a la conferencia “Presente. La política de la presencia”, de Diana Taylor, en Auditorio de la Unidad de Posgrado, unam, ir de octubre 2016. 
semillas. Más allá de acciones comunitarias y políticas públicas ya diseñadas, se desplegó una política del cuerpo presente, que en su andar diseñó demandas y sueños al volcar la mirada dentro de sí mismas. Fueron respuestas acompañadas de millones de células, fluidos y neuronas, todas entretejidas de pequeños movimientos de esperanza activa, como los llama el mismo autor.

Los performances son una acción social y política muy realista e interesante, pues algunas mujeres con ayuda de otras, y otros, tomaron la palabra, alzaron la voz $y$, emocionadas, quisieron revolucionar, activar, cambiar y dar un giro a sus vidas, sintiéndolo en todo el cuerpo.

Al caminar el centro histórico con su subjetividad, deseos, miedos, enojos, dolores y fantasías, juntas, frente a diversos públicos, incluyendo a las mismas compañeras - al ser un grupo tan diverso-, los espectadores y los otros transeúntes se afirmaban e iban sedimentando una capa más en esas calles, como plataformas, superficie de inscripción de sueños y demandas, con el cuerpo presente. Sueños que activaban un futuro en el presente, que construían el espacio para la acción y producían, sin representar, una nueva forma de política. Así, durante tres meses, la ciudad tomó a ratos la forma de cuerpos manifiestos de mujer.

Con acciones performáticas feministas se negociaba la alteridad en un proceso de invención colectiva de presente/futuro, pues cada una buscaba/mos cosas diferentes en estos tiempos de impunidad: fin a las arbitrariedades, a las violaciones, a las desavenencias; sanar, dejar de estar incómodas, endeudadas, violentadas, enojadas, no valoradas y hacerse de un nuevo cuerpo de respeto, de gozo y de nuevas decisiones, para estar mejor.

Gracias a este arte social del performance, intentamos desde el acting que se produce, dejar de lado el cuerpo que diseña el capitalismo; un cuerpo social y político enfermo, sin conciencia, que sirve solo para guerrear, escindido, adicto a los enojos por tener miedo, y construimos, por momentos y como proceso, un conocimiento colectivo esperanzador. Intentamos dejar los diseños de un pensamiento distópico que nos dice sálvate si puedes, de individualismo, de desigualdad e injusticia, de burlas y violencia, el de los gestos del bullying, gracias a que nos producimos conversando y mostrándonos. Caminamos con la utopía encarnada en interacciones de cuidado de sí y de los otros, y con ese afecto producido le dimos la vuelta a ese cuerpo silenciado. Con el cuerpo encarnado por nosotras mismas de vuelta, por un momento, rechazamos el del éxito, el del estrés, el del desamor, el patriarcal, el blanqueado, el por tanto tiempo colonizado, despertando carne, neuronas, piel, como materia prima para nuevas interacciones basadas en 
derechos, no solo en la reedición de un ethos cultural anquilosado en muchas de sus aristas, que tiene que ver con lo estético, político y, sin duda, con lo económico.

\section{Bibliografía}

Ahmed, Sara (2015), La politica cultural de las emociones, México, PUeg-unam. Appadurai, Arjun (2013), El rechazo de las minorías, México, Tusquetes Editores. Arditi, Benjamín (2013),"Las insurgencias no tienen un plan: ellas son su propio plan: performativos políticos y mediadores evanescentes", Dissidence Revista e-misférica, Io(2), Nueva York, en $<$ http://hemisphericinstitute. org/hemi/en/e-misferica-IO2 > [consulta: 5/II/2016].

Arendt, Hannah (1983), Eichmann en Jerusalén. Un estudio sobre la banalidad del mal, Barcelona, De Lumen.

Bishop, Claire (2016), Infiernos artificiales. Arte participativo y políticas de la espectaduría, Ciudad de México, Taller de Ediciones Económicas.

Boltanski Luc y Eve Chapello (2002), El nuevo espíritu del capitalismo, Madrid, Ediciones Akal.

Bolvillani, Andrea (2013), "Saberes apasionados: horizontes de construcción de conocimiento de las subjetividade(s) política(s)”, en Claudia Piedrahita, Álvaro Díaz y Pablo Vommaro (comps.), Acercamientos metodológicos a la subjetivación politica: debates latinoamericanos, Bogotá, Universidad Distrital Francisco José de Caldas/Clacso, pp. 83-1oo.

Butler, Judith (2002), Cuerpos que importan. Sobre los limites materiales y discursivos del "sexo", Barcelona, Paidós.

Berlau, Ruth (1995), Una vida con Brecht: Memorias de Ruth Berlau, Madrid, Trotta.

Castañeda Rodríguez-Cabo, J. Francisco (1983), La ley del valor y la subjetividad, tesis de doctorado inédita, París VII, Universidad de Jussieu.

Clough, Patricia T. (2010), "The Affective Turn: Political Economy, Biomedia, and Bodies", en Melissa Gregg y Gregory Seigworth (coords.), The Affect Theory Reader, Durham, Duke University Press, pp. 206-227.

De Solà-Morales, Ignasi (2008), De cosas urbanas, Barcelona, Editorial Gustavo Gili, pp. 17-28.

Didi-Huberman, George (2007), La invención de la bisteria: Charcot y la iconografía de la Salpêtrière, Madrid, Ensayos Arte Cátedra.

Domínguez Ruvalcaba, Héctor (2015), La Nación Criminal, México, Ariel. 
Expósito, Francisca (201I), “Violencia y género”, Mente y cerebro, 48, mayo-junio, pp. 20-25.

Fischer-Lichte, Erika (20II), Estética de lo performativo, Madrid, Abada Editores. Flores, Fátima (20I2), "Representación social y género: una relación de sentido común”, en Norma Blazquez Graf, Fátima Flores Palacios y Maribel Ríos Everardo (coords.), Investigación feminista: epistemología, metodología y representaciones, México, unam, pp. 339-358.

Freud, Sigmund (1988), Análisis fragmentario de un caso de histeria. Caso Dora en Obras completas, vol. vir, Buenos Aires, Amorrortu.

Freud, Sigmund (2014), Estudios sobre la histeria, México, Lecorum Editores. Foucault, Michel (2002), Vigilar y castigar, Buenos Aires, Siglo XXI Editores, pp. 6-3I.

Fuentes Zurita, María Cristina (2015),"Formación no convencional en los cibercafés: un andamiaje conceptual”, Polis, II(2), pp. I5I-185.

Fuentes Zurita, María Cristina y Evelyn Guadalupe Cázares (2016), "Co-producción de conocimiento digital en red. La colaboración desde los salones de clases", en Víctor Gerardo Cárdenas González (coord.), A plicaciones del enfoque de redes sociales al estudio de problemas de la realidad contemporánea en México, Ciudad de México, Gedisa, pp. 195-225.

Gómez, Jairo (2013), "La investigación de la subjetividad: entre la ficción y la verdad", en Claudia Piedrahita, Álvaro Díaz y Pablo Vommaro (comps.), Acercamientos metodológicos a la subjetivación política: debates latinoamericanos, Bogotá, Universidad Distrital Francisco José de Caldas/ Clacso, pp.3I-49.

Garbayo Maeztu, Maite (2012), “Dar algo a alguien”, Pipa, 2, diciembre.

Garbayo Maeztu, Maite (2016a), "Dar presencia al cuerpo: prácticas performáticas en el tardofranquismo", Anales de Instituto de Investigaciones Estéticas, 38(108), México, unam, pp. I23-I47.

Garbayo Maeztu, Maite (20I6b) "Se me enchinó el cuerpo en una musiquita muy rara que realmente no sé cómo se llama”, Petunia, 7.

Jacobs, Jane ([1973] 2013), Muerte y vida de las grandes ciudades, Madrid, Ediciones Península.

Lacan, Jacques. (1977), “Consideraciones sobre la histeria”, conferencia impartida en Bruselas, 26 de febrero.

Lacan, Jacques (2006), El Seminario, libro 23, El sinthome, Buenos Aires, Paidós. Lederach, John Paul (2016), La imaginación moral. El arte y el alma de la construcción de la paz, Bogotá, Semana Libros. 
Lee, Vernon y Clementine Anstruther-Thomson (1912), Beauty and Ugliness and Other Studies in Psychological Aesthetics, Londres/Nueva York, John Lane / The Bodley Head / John Lane Company.

Le Breton, David (2002), Antropología del cuerpo y modernidad, Buenos Aires, Nueva Visión.

Lindón, Alicia (2007),"La construcción social de paisajes invisibles y del miedo", en Joan Nogué (coord.), La construcción social del paisaje, Madrid, Editorial Biblioteca Nueva, pp. 213-236.

Maffesoli, Michel (2007), En el crisol de las apariencias, México, Siglo XXI Editores.

Maffesoli, Michel (2014), El regresar el tiempo: formas elementales de la posmodernidad, México, Siglo XXI Editores.

Mayer, Mónica (2010), "Arte y rebeldía", Ibero, revista de la Universidad Iberoamericana, $\mathrm{II}(8)$, junio-julio, pp. 22-26.

Maalouf, Amin (2012), Los desorientados, Madrid, Alianza Editorial

Merleau-Ponty Maurice (1994), Fenomenología de la percepción, Madrid, Planeta Agostini.

Muñiz, Elsa (2015),"Las prácticas corporales. De la instrumentalidad a la complejidad", en Elsa Muñiz (comp.), El Cuerpo. Estado de la cuestión, México, UAM / La Cifra Editorial, pp. 29-58.

Nussbaum, Martha (2014), Emociones politicas ¿Por qué el amor es importante para la justicia?, México, Paidós.

Norandi, Mariana (2010),"Performances sobre ser mujer y trabajar en el Centro Histórico", Sociedad y Justicia, La Jornada, México, II de junio.

Piedrahita, Claudia (2013),"Reflexiones metodológicas. Acercamiento ontológico a las subjetivaciones políticas”, en Claudia Piedrahita, Álvaro Díaz y Pablo Vommaro (comps.), Acercamientos metodológicos a la subjetivación politica: debates latinoamericanos, Bogotá, Universidad Distrital Francisco José de Caldas/Clacso, pp. 15-30.

Quesada, Fernando (2013), Del cuerpo a la red. Cuatro ensayos sobre la descorporeización del espacio, Madrid, Ediciones Asimétricas.

Rabotnikof, Nora (2008), "Lo público hoy: lugares, lógicas y expectativas". Iconos. Revista de ciencias sociales, 32, septiembre, pp. 37-48

Ruiz Trejo, Marisa (2015), Epistemologías articulatorias. Amor al aire: antropología situada de las radios latinas en Madrid", tesis doctoral, Universidad Autónoma de Madrid, Cap. I, pp. I8-IO3 
Ruiz Trejo, Marisa y S. García Dauder (2016), "Experiencias corporales, comprometidas y reflexivas en investigación activista", Memorias del Onceavo Congreso Iberoamericano: Ciencia, Tecnología y Género, San José: INIE (Colección Yigüirro), disponible en <https://www.academia. edu/2747176I/Experiencias_corporales_comprometidas_y_reflexivas_en_investigaci\% $\mathrm{C}_{3} \% \mathrm{~B}_{3}$ _activista $>$ [consulta: $\mathrm{ro} / \mathrm{oI} / 2017$ ].

Ruvalcaba, Patricia (2010), "Cuerpos manifiestos: el Centro en femenino", Km cero, junio.

Sennett, Richard (2003), Introducción, en Carne y piedra, El cuerpo y la ciudad en la civilización occidental, Madrid, Alianza Editorial, pp. 17-30.

Stavrides, Stavros (2016), Hacia la ciudad de los umbrales, México, Akal.

Sontag, Susan (2003), Ante el dolor de los demás, Madrid, Random House.

Taylor, Diana (2012), Performance, Buenos Aires, Asunto Impreso Ediciones.

Taylor, Diana y Marcela Fuentes (coords.) (20II), Estudios Avanzados del Performance, México, Fondo de Cultura Económica.

Therborn, Göran (2015), La desigualdad mata, Madrid, Alianza Editorial.

Turner, Víctor (1988), El proceso ritual, Madrid, Taurus Alfaguara.

Varela, Stephanie (2016), Dimensiones de lo politico en la danza contemporánea: el cuerpo en movimiento, el espacio público y el performance como metodología de análisis, Proyecto de tesis de la maestría en Comunicación y Política de la UAM-Xochimilco [en proceso de revisión].

Weber, Max (1968), On Charisma and Institution Building, Chicago, The University of Chicago Press.

Winnicotte, Donald (1993), Los procesos de maduración y el ambiente facilitador, Buenos Aires, Paidós.

Zirión Pérez, Antonio (2015), “Miradas cómplices: cine etnográfico: estrategias colaborativas y antropología visual aplicada", Iztapalapa. Revista de Ciencias Sociales y Humanidades, 36(78), enero-junio, pp. 45-70.

Resumen CuRricular

Profesora investigadora en el Departamento de Sociología de la Universidad Autónoma Metropolitana, Unidad Iztapalapa. Integrante del Cuerpo Académico Estudios Socioespaciales. Psicóloga por la UNAm, maestra en Sociología del Conocimiento por la Universidad de Jussieu, Paris vir. Doctora en Educación por el Instituto de Ciencias de la Educación de la Universidad Autónoma del 
Estado de Morelos en cotutela con la Universidad Sorbona Nueva, París III. En 2012 publicó el libro El edén de los jóvenes: los cibercafés populares. Juan Pablos Editor/UAm-I, División de Ciencias Sociales y Humanidades. Posteriormente, desarrolló el proyecto "La nueva mirada UAM-I: del aula al ciberespacio" para la producción y reflexión de material digital educativo para jóvenes. Últimos artículos: en coautoría con Evelyn Guadalupe Cázares (2016) "Co-producción de conocimiento digital en red. La colaboración desde los salones de clases", en Aplicaciones del enfoque de redes sociales al estudio de problemas de la realidad contemporánea en México, coordinado por Víctor Gerardo Cárdenas González, Ciudad de México, Editorial Gedisa, pp. 195-225. Y en (2015) "Formación no convencional en los cibercafés: un andamiaje conceptual", Polis, Segundo semestre, vol. II, núm. 2, pp. 15I-185. Otros temas de interés: subjetividades, géneros y esfera pública.

Citar como: Fuentes Zurita, María Cristina (2017), "Del desencanto al encantamiento del mundo: el cuerpo de los sueños y el cuerpo presente", Iztapalapa. Revista de Ciencias Sociales y Humanidades, núm. 82, año 38, enero-junio de 20I7, ISSN: 2007-9I76; pp. 13-48. Disponible en <http://revistaiztapalapa.izt.uam. $\mathrm{mx} /$ index.php/izt/issue/archive $>$. 